\title{
Wyrok Sądu Metropolitalnego w Katowicach (c. Sobański) z 02.12.2005 r. z tytułu niezdolności do podjęcia istotnych obowiązków małżeńskich
}

Ius Matrimoniale 11 (17), 171-177

2006

Artykuł został opracowany do udostępnienia w internecie przez Muzeum Historii Polski w ramach prac podejmowanych na rzecz zapewnienia otwartego, powszechnego i trwałego dostępu do polskiego dorobku naukowego i kulturalnego. Artykuł jest umieszczony w kolekcji cyfrowej bazhum.muzhp.pl, gromadzącej zawartość polskich czasopism humanistycznych i społecznych.

Tekst jest udostępniony do wykorzystania w ramach dozwolonego użytku. 


\section{Wyrok Sądu Metropolitalnego w Katowicach (c. Sobański) z 2.12.2005 z tytułu niezdolności do podjęcia istotnych obowiąz- ków małżeńskich}

\section{Przebieg sprawy:}

TP i AA zawarli małżeństwo 30.8 .1997 w (...). Ważność tego małżeństwa zaskarżyła AA 16.11.1999 w Sądzie (...). Sprawę prowadzono z tytułu niezdolności do podjęcia istotnych obowiązków małżeńskich zarówno powódki jak i pozwanego. Sprawa zakończyła się wyrokiem z 19.12.2001 stwierdzającym, że udowodniono nieważność małżeństwa z obydwu rozpatrywanych tytułów. Zgodnie z k. 1682 \$1 sprawa znalazla się w Trybunale II instancji, który dnia 27.5.2002 postanowił skierować ją na drogę zwyczajnego postępowania. Po przesłuchaniu nowych świadków oraz zasięgnięciu opinii kolejnego biegłego zamknięto postępowanie 4.10.2003, a dnia 10.3.2004 sędziowie wydali wyrok stwierdzający, że nie udowodniono nieważności małżeństwa i tym samym uchylili w całości wyrok Trybunału I instancji. Na prośbę powódki Najwyższy Trybunał Sygnatury Apostolskiej reskryptem z 9.8.2004 (Prot. N. 36282/04 CP) wyznaczył Sąd Metropolitalny w Katowicach do rozpatrzenia i osądzenia sprawy w trzeciej instancji. Akta sprawy nadeszly 10.9. i 20.11.2004. Sprawę przyjęto do procesu 15.11.2004. Jego przedmiotem jest pytanie, czy udowodniono nieważność małżeństwa z tytułu niezdolności czy to powódki czy to pozwanego do podjęcia istotnych obowiązków małżenskich. Instrukcję sprawy uzupełniono zgodnie z wnioskiem powódki oraz przez zasięgnięcie dodatkowej opinii biegłego.

\section{Prawny i faktyczny stan sprawy:}

1. Normy prawa - zarówno materialnego jak i formalnego - znajdujące zastosowanie w rozpatrywanej sprawie wylożono wystarczająco 
jasno w wyrokach poprzednich instancji i nie zachodzi potrzeba powtarzania ich.

2. Mimo że akta sprawy I instancji zawierają zeznania dziewięciorga świadków, w wyroku wykorzystano odnośnie do pozwanego jedynie zeznania matki i siostry powódki, zaś w odniesieniu do powódki stwierdzono tylko ogólne, że ,według kolejnych świadków powódka była zupełnie niezależna od matki, a matka była wobec niej nadopiekuńcza", przy czym faktycznie wskazano tylko zeznania trzech świadków. Wypada też zauważyć, że przytoczone zeznania matki i siostry powódki zawierają jedynie oceny, a nie fakty. Oczywiste jest przeto, że wyrok Trybunału I instancji nie mógł opierać się na zeznaniach świadków (zwłaszcza, że zeznania te kłócą się z zeznaniami innych świadków), lecz na opinii sporządzonej przez bieglą.

3. Biegła istotnie wydała opinię prowadzącą do wniosku, że tak jedna jak i druga strona nie byly zdolne podjąć istotnych obowiązków małżeńskich. Odnośnie do powódki pisze biegła, że „decyzję o malżeństwie podjęła impulsywnie, bez głębszej refleksji...”, a „po tak podjętej decyzji nie była w stanie podjąć i wypelnić obowiązku budowania wspólnoty życia i miłości". Tak sformułowana opinia znaczy - po pierwsze - ze powódka była niezdolna nie do podjęcia istotnych obowiązków małżeńskich, lecz jedynie do ich wypełniania w tym właśnie małżeństwie, i - po wtóre - że niezdolność ta byla spowodowana sytuacyjnie, faktem zawierania małżeństwa „,bez glębszej refleksji”. Tej refleksji może i brakło, znikąd jednak nie wynika, że powódka nie byla do niej niezdolna.

Ów „brak głębszej refleksji” jest też motywem przewodnim opinii biegłej I instancji o pozwanym. Biegła pisze wyraźnie: „uważam, iż po tak podjętej decyzji nie był zdolny do podjęcia i wypełnienia obowiązku budowania wspólnoty życia i miłości”. Czyli: nie tyle cechy psychiczne pozwanego, ile to, jak doszło do ślubu, spowodowało, że nie był on zdolny podolać obowiązkom małżeńskim. Już sama konkluzja biegłej, wedle której „na losy tego małżeństwa wplyw miała przede wszystkim niedojrzale podjęta decyzja o ślubie obu stron”, każde wątpić w możliwość orzekania o niezdolności z racji psychicznych do podjęcia istotnych obowiązków małżeńskich (a z tytułu braku dostatecznego rozeznania sprawy nie rozpatrywano). Niedojrzala postawa czy niedojrzała decyzja niekoniecznie świadczy o niedojrzalej osobowości.

4. Wlaśnie na to zwraca uwagę biegła powolana w II instancji. Podzielając charakterystykę postępowania stron zarysowaną przez bieglą 
I instancji pisze ona: „Powyższe postępowanie nie jest jednak tożsame z posiadaniem niedojrzałej osobowości, a jedynie z przyjęciem określonej postawy”. Konkluzja tej biegłej brzmi: „Osobowość powódki przedstawia się dość spójnie i nie sposób zarzucić badanej, że byta niedojrzała, badź też uzależniona od matki. W osobowości pozwanego zauważyć można wiele różnorodnych, czasem przeciwstawnych, cech, z których jedynie duża impulsywność wydaje sie mieć destrukcyjny charakter. Impulsywność ta świadczy o swoistej reaktywności układu nerwowego. Niekontrolowana może w znacznym stopniu utrudniać relacje interpersonalne. Nie stanowi ona jednak o niedojrzatości czy też o braku psychicznej zdolności do podjęcia przez pozwanego obowiazków matżenskich".

5. Trybunał II instancji uzupełnił instrukcję sprawy nie tylko zasięgając opinii drugiej biegłej, lecz także przesłuchując dwóch dalszych świadków. Dokonawszy oceny materiału dowodowego Trybunał przyjął, że pozwany jest $z$ usposobienia nerwowy i porywczy, ale też energiczny, szybki, zaradny, przewidujący. Trybunał uznał za zasadną opinię biegłej powołanej w tej instancji, zwłaszcza że nikt spośród świadków nie dostrzegl u pozwanego braków psychicznych.

Odnośnie do niezdolności powódki Trybunał II instancji nie znalazł żadnych argumentów za tezą powództwa.

6. Powódka w piśmie apelacyjnym od wyroku II instancji dała wyraz przekonaniu, ,że z lektury akt dowodowych niezbicie wynika, że w momencie celebracji malżeństwa zarówno po stronie powódki jak i po stronie pozwanego miało miejsce poważne zakłócenie w decyzji wyrażenia zgody na zawarcie małżeństwa $z$ powodu niedojrzałości osobowościowej w rozumieniu prawno-kanonicznym". Powódka poinformowała następnie, że dysponuje dowodem, ,który nie został przedstawiony w poprzednich instancjach", a który zamierza przedłożyć podczas ponownego przesłuchania. Tym dowodem okazała się notatka - wedle powódki - pozwanego, w której on 6.4.1997 pisze: „doprowadza mnie do rozstroju nerwowego" i „musimy się grzmocić, bo moje życie seksualne leglo w gruzach". Zeznając powódka podkreśla wagę tego dowodu, ,gdyż udowadnia dominację i jaką presję pozwany miał" względem jej osoby. Powódka twierdzi: „Uważam, że Wyrok Sadu Metropolitalnego (...) opiera się na opinii biegtego, która to biegła skupila sie na określeniu mojej osobowości w chwili przeprowadzenia badania, a nie $w$ chwili decydowania o zawarciu matżenstwa. Wplyw osobowości pozwanego, to znaczy duża impulsywność, agresja wzoledem mojej osoby, destrukcyjność, w znacznym stopniu utrudniała relacje interpersonalne 
między nami powodujac we mnie blokady psychiczne, co do wypetnienia i podjecia podstawowych obowiązów matzenskich. Ja decyzję o zawarciu matzeństwa podjętam pod wptywem pewnego nacisku pozwanego, pod wplywem obawy na jego reakcję $w$ momencie, gdybym odmówita zawarcia z nim matżenstwa. Czutam, że zawarcie matzeństwa z pozwanym jest moim btedem, ale nie miatam sit $i$ odwagi o tym powiedziec, batam się osoby pozwanego, moja blokada psychiczna nie pozwolita mi tego wypowiedzieć”. I dalej zeznaje: „Ja wewnętrznie czułam, że moja decyzja o zawarciu matżeństwa jest wynikiem nacisku pozwanego na moja osobe, to znaczy ja bytam osoba bardzo zdominowana przez pozwanego, batam sie przy nim wyrażać moja opinie lub zdanie na temat malżenstwa. $W$ momencie, kiedy zaczętam sobie zdawać sprawe z błędu, jaki popetniam decydujac sie na malżeństwo z pozwanym, nie miatam sil, aby sie przeciwstawić jego naciskom. Nie rozmawiatam z nikim na ten temat, balam sie nawet porozmawiać $z$ kimś z rodziny o moich obawach io tym, że czuje, ze to jest blędna decyzja. Przyznaje się do tego, ze przed ślubem $z$ dawalam sobie sprawe $z$ tego, ze nasze relacje sa bez uczucia $z$ mojej strony i na tyle bylam niedojrzata do tak poważnej decyzji życiowej, że nie umiatam tego wypowiedzieć i poszlam do ślubu po tym naciskiem, zdajac sobie sprawe z braku sit na wyjaśnienie tego co czuje. Pozwanemu bardzo zależalo, aby jak najszybciej wziąć ślub, zastanawialy mnie jego czeste pytania czy się nie rozmyśle".

O własnej niedojrzałości do podjęcia i wypełnienia istotnych obowiązków małżeńskich powódka jest „glęboko przekonana”, zaś niedojrzałość pozwanego uzasadnia w ponownych zeznaniach następująco: „Uważam, że ta niedojrzatość pozwanego zawiera się w tym, że nie miat on koncepcji na to, jaki mamy razem stworzyć zwiazek, nie umiat pomóc mi w rozmowach z nim, tylko wszystkie próby rozmów kończyly się któtnia i te rozmowy wykańczały mnie nerwowo, powodowały, że czułam się gorsza, pozostawatam w opinii, że nie mam wtasnego zdania, albo że moja opinia w jego oczach jest błedna. W tamtym czasie mialam jedynie 23 lata, pozwany byt moim pierwszym partnerem zyciowym, którego nie zdolatam dobrze poznać $i$ który wywieral na mnie bardzo negatywny wplyw uniemożliwiajacy mi tworzenie normalnych relacji interpersonalnych. To byta osoba, której się batam, która wywolywata we mnie lek, z która tak naprawde nie potrafilam rozmawiać, ponieważ za każdym razem balam sie jego reakcji. Pozwany dawat mi odczuć dominacje fizyczna i psychiczna".

7. Sąd zasięgnął opinii kolejnego biegłego. Opinia składa się z dwu częśsi. Pierwsza to „zaświadczenie z badania psychologicznego” prze- 
prowadzonego $\mathrm{z}$ powódką (zaproszenie wysłane pozwanemu wróciło $\mathrm{z}$ adnotacją o niepodjęciu z terminie). Konkluzja biegłego brzmi: „Wyniki przeprowadzonych badań wskazuja na wzglednie harmonijna osobowość powódki w obszarze poznawczo-wolitywnym (plany, dazzenia, odpowiedzialności dziatania), $i$ mniej harmonijng $w$ obszarze emocjonalno-popędowym (opis w zaświadczeniu) z cechami nerwicowymi. Stany emocjonalne poddawane sa ciagtej i silnej kontroli wolitywnej. Sugeruje to, że pozwana $w$ codziennych sytuacjach nie zdradza (nie doświadcza) dolegliwości opisanych w zaświadczeniu. Mogq one generować się z duzym nasileniem w sytuacjach trudnych, stresu lub kryzysu psychologicznego”. Druga część to „opinia sądowo-psychiatryczna w sprawie nieważności małżenstwa". Próbując udzielić odpowiedzi na konkretne pytania biegły pisze o nieprawidłowych cechach osobowościowych pozwanego (dominacja sfery emocjonalno-popędowej nad uczuciowo-poznawczą, niezdolność do nawiązywania „pogłębionych" relacji interpersonalnych), nie wykazujących jednak cech patologicznych w sensie klinicznym. Odstępstwo od normy to wedle bieglego trwałość tych cech i stopień nasilenia, „który można określić granicznym między normą a patologią". „W przypadku pozwanego nieprawidlowe zachowania ujawniły się w okolicznościach konieczności bezinteresownego bycia dla innych”. Pisze biegly dalej: „Należy zatem przyjąc ich wzgledna trwatość $i$ duże prawdopodobieństwo, że zachowania te będa reaktywowane $w$ sytuacjach podobnych do opisanych $w$ zeznaniach (analiza w opinii). Sa to cechy, które uniemożliwiaty funkcjonowanie w matzeństwie $i$ nie byty one zależne od cech drugiej strony. Niedojrzate cechy powódki w postaci silnej potrzeby wsparcia wyraźniej ukazaly dysfunkcje pozwanego w tym zakresie. Musiatby bowiem ofiarować sie rezygnujac $z$ wtasnej wizji matżenstwa nie mając nic $w$ zamian. Opisane wyżej okoliczności czynity pozwanego niezdolnym do wypetnienia istotnych obowiazków matżenskich takich jak budowanie wspólnoty życia $i$ mitości. Pozwanego przerastato: budowanie atmosfery poczucia bezpieczeństwa skupiat się na sobie, bezinteresowne zainteresowanie się sytuacja powódki (przeżywanymi problemami) $i$ udzielania wsparcia $w$ ich rozwiazywaniu, zrezygnowanie z pewnych form towarzyskich kontaktów na rzecz budowania relacji rodzinnych i matżenskich". Cechy powódki zdaniem biegłego utrudniały funkcjonowanie w małżeństwie, ale nie czyniły powódki niezdolnej do podjęcia istotnych obowiązków małżeńskich. Generalna konkluzja biegłego brzmi jednak: ,Jak zostato wykazane w opinii, przyczyna rozpadu matżeństwa byto wspólwystępowanie $i$ oddziaływanie na 
siebie z jednej strony cechy niedojrzatości po stronie powódki, a z drugiej rozpoznane zaburzenia po stronie pozwanego. Analiza zachowań stron $w$ okresie przed i poślubnym, daje podstawe do stwierdzenia, że zwiazek opierat się na deficytowych i niedojrzatych potrzebach stron, co w konsekwencji musiało doprowadzić do rozpadu zwiazku".

8. Odnośnie do niezdolności psychicznej powódki do małżeństwa postępowanie w III instancji nie wniosło nowych dowodów ani argumentów. Nie dotyka istoty sprawy zeznanie powódki, wedle której osobowość pozwanego wywoływała u niej "blokady psychiczne" $\mathrm{i}$ „utrudniała relacje interpersonalne". Taka interpretacja sytuuje niezdolność do małżeństwa po stronie pozwanego.

9. Pozwany istotnie rysuje się w zeznaniach powódki i jej matki jako postać skupiająca w sobie wiele cech negatywnych, z kolei świadkowie z rodziny pozwanego oceniają go inaczej. Spośród trojga bieglych powolanych w sprawie badanie pozwanego przeprowadziła tylko biegla II instancji, która - jak to zaznaczono już wyżej - nie znalazła podstaw do oceny pozwanego jako niezdolnego do podjęcia istotnych obowiązków małżeńskich. Biegła I instancji wydała opinię o niezdolności pozwanego do budowania wspólnoty życia. Sąd nie podziela zastrzeżeń obrońcy węzła małżeńskiego II instancji co do wypowiadania się biegłej o niezdolności psychicznej stron (po to powoluje się biegłego, sądy orzekają natomiast o nieważności małżeństwa), problem natomiast w tym, że opinia biegłej opiera się na interpretacji faktów, których nie wskazala. Również biegły III instancji wysuwa twierdzenia, których przesłanek nie sposób dostrzec. Pisze: „Od szkoły podstawowej pozwany przejawiał nieprawidłowości w zachowaniu”. Nie widać innych przesłanek takiego twierdzenia jak tylko zeznanie powódki: „Bardzo szybko, już w szkole podstawowej, zacząl palić. Jego wybryki w szkole: wagary, przykre numery lagodziła jego mama, która była nauczycielką". Powódka mogłaby to wiedzieć jedynie ze słyszenia, ale taka zasłyszana, nie potwierdzona przez świadków znających pozwanego w czasach szkolnych, informacja nie upoważnia do wypowiadania tak kategorycznej opinii jak to uczynił biegły. Ustalenia dotyczące okresu poślubnego biegly oparł wyłącznie na zeznaniach powódki i jej matki (na wielokrotnie przywołanych stronach I, 27-31 i I, 48-50 znajdują się zeznania tych osób). Biegły powoluje się też na „własną ścieżkę interpretacyjną wyników uzyskanych w badaniu w dniu 24-07-2003", ale w aktach nie ma śladu takich badań (biegla II instancji badala pozwanego 12.4.2003). Jeśli natomiast biegły miał na myśli badania przeprowa- 
dzone przez biegłą II instancji, to biegły nie uzasadnia, dlaczego jego „ścieżkę interpretacyjną" należy uznać za słuszną. Co więcej, biegly uważa, że skoro badania przeprowadzono „co najmniej cztery lata od rozstania się stron”, to "nie można w oparciu o otrzymane wyniki wnioskować o dojrzałości czy też niedojrzałości stron". Biegły tym samym popada w sprzeczność z samym sobą, skoro jednak wyniki takich badań poddaje własnej interpretacji. Biegły słusznie zauważa, że opinie zależą od oceny wiarogodności zeznań, ale nie uzasadnia, dlaczego uznał zeznania pozwanego za nieprawdziwe, a zeznania wszystkich świadków poza matką i siostrą powódki zupełnie pominął.

10. Sąd docenia starania powódki - podzielane przez pozwanego o uregulowanie jej sytuacji kościelnej, Sąd zdaje sobie sprawę ze znaczenia, jaką dla wiernych ma orzeczenie dotyczące ich małżeństwa, a także z oczekiwań wiązanych przez strony wnoszące sprawę do sądu kościelnego. Sąd musi jednak orzekać zgodnie z prawem. Sąd respektuje ,glębokie przekonanie" powódki o nieważności małżeństwa, a także o czynnikach powodujących tę nieważność, ale orzeczenie Sądu nie może opierać się na przekonaniu stron, lecz na faktach, których przyporządkowanie do norm prawa pozwala osiągnąć moralną pewność, że małżeństwo zostało zawarte nieważnie, w tym przypadku nieważnie z powodu niezdolności - mającej przyczynę w sferze psychicznej - do wypelnienia, a tym samym do podjęcia, istotnych obowiązków małżeńskich. Powódka zarzuca Trybunałowi II instancji niedostateczną „analizę odczuć” i brak ,przeanalizowania” jej przeżyć przed ślubem. Można uznać, że owe odczucia i przeżycia rzutowały na poślubne życie stron, a konkretnie na ich postawę i wzajemny stosunek, trudno jednak wyprowadzić stąd wniosek o powodowanej osobowościowymi czy psychicznymi cechami którejś ze stron (wzgl. obydwu) niezdolności do nawiązania wspólnoty małżeńskiej wraz z jej radościami i obowiązkami.

W takim stanie sprawy Sąd nie osiągnął moralnej pewności o niezdolności - w chwili zawierania małżeństwa - czy to pozwanego czy to powódki do podjęcia istotnych obowiązków małżeńskich. Tak więc Sąd odpowiada przecząco na obydwa pytania procesowe i orzeka, że nie udowodniono nieważności małżeństwa. Tym samym Sąd zatwierdza wyrok Trybunału II instancji. 